\title{
Peranan Tuan Guru, Ormas Islam Nahdlatul Wathan di Lombok Sebagai Wadah Ajaran Keagamaan dan Sosial (Islam)
}

\author{
Jun Mawalidin \\ UIN Sunan Kalijaga, Yogyakarta, Indonesia \\ joenjun98@gmail.com
}

\begin{abstract}
The teachings of Islam for the Sasak people get a very high place in carrying out their daily religious life in accordance with the teachings of their religion. The purpose of this study is to analyze theoretical analysis on Islamic religious traditions that have existed in the Sasak community since the beginning of their entry, placing more emphasis on strengthening religious practices or rituals that at a glance place great importance on religious expression. This research method uses the library research method about the role of the Nahdlatul Wathan Islamic mass organization figure in Lombok. The results showed that Nahdlatul Wathan focused on three areas of development, namely education, social and da'wah. The presence of Tuan Guru on the island of a thousand mosques gives a different feel. Bahklan is a characteristic of society, its influence can be felt in various fields, not only in the field of education, in politics but also in the executive field.
\end{abstract}

Keywords: Tuan Guru, Community, Lombok, Nahdlatul Wathan.

\begin{abstract}
Abstrak
Ajaran Islam bagi masyarakat sasak mendapatkan tempat yang sangat tinggi dalam menjalankan kehidupan keagamaannya sehari-hari sesuai dengan ajaran agama yang dianut. Tujuan dari penelitian ini adalah melakukan telaah teori analisis pada Tradisi keagamaan Islam yang terdapat di masyarakat Sasak sejak awal masuknya, lebih menekankan pada penguatan-penguatan amalan atau ritual keagamaan yang secara sepintas sangat mementingkan ekspresi keagamaan. Metode penelitian ini menggunakan metode library research tentang peranan tokoh ormas islam nahdlatul wathan yang ada di lombok. Hasil penelitian menunjukkan bahwa Nahdlatul Wathan fokus pada tiga bidang pembangunan, yaitu pendidikan, sosial dan dakwah. Kehadiran Tuan Guru di pulau seribu masjid memberikan nuansa yang berbeda. Bahklan merupakan ciri khas
\end{abstract}


masyarakat, pengaruhnya dapat dirasakan di berbagai bidang, tidak hanya di bidang pendidikan, di bidang politik tetapi juga di bidang eksekutif.

Kata kunci: Tuan Guru, Masyarakat, Lombok, Nahdlatul Wathan.

\section{A. Pendahuluan}

Ajaran Islam sangat penting bagi masyarakat Sasak karena mereka menjalankan kehidupan keagamaan sehari-hari sesuai dengan ajaran agama yang diterima. Kuatnya tradisi keagamaan Islam ini terlihat dari banyaknya jumlah rumah ibadah. Karena itu, tak heran jika sekelompok orang menyebut Pulau Lombok sebagai pulau seribu masjid. Juga fenomena peningkatan jumlah jamaah haji setiap tahunnya, yang menjadi indikator keseriusan pemujaan masyarakat Sasak.

Tradisi keagamaan Islam yang telah ada pada masyarakat Sasak sejak awal masuknya lebih menekankan pada penguatan praktik atau ritual keagamaan yang sekilas sangat mementingkan ekspresi keagamaan dalam bentuk model dasar ritualitas yang kemudian menjadi model unik (particular pattern) dengan mendahulukan kepentingan (zhahir an-nas) dalam pengetahuan ajaran Islam. Islam merupakan faktor penting dalam masyarakat Lombok. Hampir 95 persen penduduk pulau itu adalah orang Sasaki dan hampir semuanya adalah Muslim. Seorang etnografer juga pernah mengatakan bahwa “menjadi orang Sasak berarti menjadi seorang Muslim”. Meskipun pernyataan ini tidak sepenuhnya benar (karena mengabaikan popularitas Sasak Boda). Namun, sentimen ini dianut oleh mayoritas penduduk Lombok yang beragama Islam dan hanya sebagian kecil non-Muslim, seperti Hindu atau Kristen, yang disambut oleh mayoritas pendatang dari etnis seperti Bali dan Tionghoa (Masnun, 2008).

Perkembangan Islam di Lombok sejalan dengan munculnya para penyebar Islam (penafsir Dakwah), sebagaimana diajarkan Sunan Giri, untuk membebaskan masyarakat dari animisme dan menjadi masyarakat yang agamis, yaitu Islam. Setelah itu, lahirlah tokoh-tokoh ulama Lombok yang dimulai pada awal abad ke-20 yang disebut Tuan Guru. Tuan Guru adalah sebutan atau himbauan kepada orang alim yang memiliki ilmu agama yang luas dan mendalam untuk melanjutkan dakwah para pendahulunya, yang 
meninggalkan warisan intelektual yang sangat berharga dan membebaskan masyarakat dari kebodohan dan keterbelakangan akibat penjajahan Belanda.

Tuan Guru di Lombok kini menjadi salah satu pemangku kepentingan yang memiliki tanggung jawab yang sama dengan pemangku kepentingan lokal. Tuan Guru, baik sebagai pengurus pondok pesantren, pemimpin, masyarakat, pengawas madrasah, pengurus/anggota partai politik, dan kepala rumah tangga, diposisikan secara strategis untuk memotivasi masyarakat, meningkatkan partisipasi, dan memberdayakan masyarakat. Pulau Lombok untuk mengejar dan melanjutkan pendidikannya. Untuk mencapai tujuan tersebut, peran Tuan Guru dan juga tokoh agama dalam asketisme, pendidikan dan politik diperlukan untuk berkomunikasi dengan masyarakat, orang tua siswa, pemerintah daerah dan tokoh masyarakat, sehingga semakin banyak orang (siswa) menarik, untuk mengikuti magang di pulau lombok. (Firdaus; Engkus 2012).

Dalam ranah kegiatan masyarakat Sasak-Lombok, salah satu tujuan perubahan atau pemimpin bagi perubahan sosial adalah Tuan Guru. Beliau merupakan sosok yang berperan penting dalam perubahan sosial masyarakat Sasak. Untuk memperjelas penelitian ini, ada dua hal yang ditekankan, yaitu: Pertama, Tuan Guru yang dimaksud di sini adalah Tuan Guru Lombok abad ke-20 dengan berbagai perannya dalam perubahan sosial hingga saat ini. Kedua, Tuan Guru sebagai tokoh agama ormas Nahdlatul Wathan tidak dianalisa secara personal dalam penelitian ini, melainkan lebih membahas peran sosial (social roles). Tokoh agama dalam perubahan sosial masyarakat Muslim Sasak melalui pendidikan dan dakwah (ceramah, pengajian di masyarakat atau lembaga pendidikan) dan bukan dalam masalah politik praktis. Di antara Guru Guru yang memainkan peran penting dalam perubahan sosial di pulau Lombok sekitar abad ke 20 ini adalah Tuan Guru Kiyai Haji M. Zainuddin Abdul Majid (Lombok Timur), TGKH. Muhammad Djuaini Mukhtar (Lombok Barat), TGKH. Safwan Hakim (Lombok Barat), TGKH. Turmuzi (Lombok Tengah) dan tokoh agama lainya. Peran Tuan Guru abad ke20 saat ini perlu adanya penjelasan karena menurut Jamaludin, sebelum abad ke-20, adanya kemunculan tokoh agama yaitu Tuan Guru di pulau Lombok dengan corak dakwah masing-masing seperti TGH. Umar Buntimbe (Pertengahan abad 18), TGH. 
Mustafa Sekarbela (akhir abad 18), TGH. Amin Sesela (Akhir Abad 19) dan lain sebagainya (Mohamad, 2016).

Keberadaan ormas Nahdlatul Wathan sebagai ormas Islam di Lombok berperan sebagai mediator perubahan masyarakat. Memiliki akidah, prinsip, tujuan, dan ruang lingkup organisasi yang jelas. Organisasi Nahdlatul Wathan menganut paham aqidah Islam Ahlu-al-Sunnah wa al-Jamaa'ah ala Madzahib al-Iman al-Syafi'I dan

Berdasarkan konstitusi negara yakni Pancasila sesuai dengan Undang-Undang Nomor 8 Tahun 1985 tentang organisasi kemasyarakatan. Sejak awal berdirinya. Organisasi bedasarkan Islam dan kekeluargaan. Asasnya berlaku hingga Muktamar ke-3, dan kemudian dirubah dengan Ahlu al-Sunnah wal al-Jamaah ala Madzahib al Imam alSyafii. Perubahan ini terjadi sebelum pertarungan antara dua madrasah utama, NWDI dan NBDI. Urgensi atau tujuan organisasi ini adalah Li I'laai Kalimatillah wa Izzi al-Islam wa al-Muslimin dengan maksud dan tujuan menggapai keselamatan serta kebahagiaan hidup di dunia maupun di akhirat berdasarkan pemahaman ajaran-ajaran keislaman atau Ahlu al-Sunnah wa al-Jama'ah ala Madzahib al-Iman al-Syafi'I Radiyallahu'anhu (Lombok Group, 2017).

\section{B. Pembahasan}

\section{Ormas Islam Nahdlatul Wathan di Lombok}

Organisasi Kemasyarakatan atau disingkat Ormas adalah istilah yang digunakan di Indonesia untuk organisasi massa yang didirikan untuk tujuan tertentu atas dasar kesepakatan bersama. Misalnya, bentuk dapat dibentuk berdasarkan beberapa kesamaan atau tujuan; Agama, pendidikan dan masyarakat. Oleh karena itu, ormas Islam dapat diartikan sebagai ormas yang bertujuan untuk memperjuangkan tegaknya Islam menurut Al-Qur'an dan As-Sunnah serta memajukan umat Islam di berbagai daerah; di bidang agama, pendidikan, sosial dan budaya (Abdul, 2015). Ormas Islam memegang peranan penting dalam kegiatan sosial keagamaan, pemikiran dan gerakan pembaruan dalam Islam merupakan proses yang tidak pernah berhenti. Tidak bisa dipungkiri juga bahwa pada waktu-waktu tertentu (Fitriyani, 2010). 
Penyelidikan ormas Islam di Lombok dari sejarah sejarahnya memiliki kekuatan yang dahsyat dalam kepemimpinan sosial-keagamaan. Nahdlatul Wathan adalah sebuah organisasi masyarakat muslim yang berbasis di Lombok, Nusa Tenggara Barat, didirikan oleh Tuan Guru Haji Muhammad Zainuddin Abdul Madjid, yang bermarga Muhammad Saggaf lahir pada hari Rabu 18 Rabi'ul Awal 1316 H., yang bertepatan dengan tanggal 20 Hijriyah. April 1908, lahir di Kampung Bermi, Desa Pancor, Kecamatan Rarang Timur (sekarang Kecamatan Selong), Lombok Timur, Nusa Tenggara Barat. Kelahiran TGKH. Muhammad Zainuddin Abdul Madjid pada tahun 1908 terjadi sejumlah peristiwa penting di Nusantara dan di Lombok, sebelum dan sesudahnya. Pada tahun pertama abad ke-20, pemerintah Hindia Belanda menerapkan kebijakan politik etis di jajahan Hindia Belanda sebagai akibat dari pidato ratu muda Belanda (saat itu berusia 20 tahun) Wilhelmina Helena Pauline Marie van Orange-Nassau.

Selesainya Muhammad Zainuddin Muda menimba ilmu dan pulang ke Lombok di Nusa Tenggara Barat Tahun 1934 beliau langsung mendirikan Pesantren al-Mujahidin menggunakan sarana dan prasarana bangunan tempat ibadah kecil untuk masyarakat sekitar di dekat tempat tinggal di Bermi, Pancor Lombok Timur. Muhammad Zainuddin muda melamar pemerintah kolonial Hindia Belanda Lombok di Selong untuk izin membuka madrasah. Madrasah yang didirikan itu bernama Nahdlatul Wathan Diniyah Islamiyah (NWDI). Pada tahun berikutnya, yakni 22 Agustus 1937 Madrasah NWDI di resmikan untuk di gunakan dalam kegiatan keagaman. Kelompok belajar di kelompokkan menjadi tiga macam yaitu: tingkat Ilzamiyah, Tahdiriyyah dan Ibtidaiyah. Kegiatan beajar mengajar sebagai tempat menimba ilmu agama ini terus mengalami kemajuan dan perkembangan yang baik, sehingga pelopor pendirian sekolah madrasah menjadikan hari di resmikanya yaitu pada tanggal 15 Jumadil Akhir 1356 H/22 Agustus 1937 M. sebagai bentuk perayaan perjuangan, hari peresmian madrasah ini di peringati sebagai hari ulang tahun berdirinya madrasah Nahdlatul Wathan.

Layanan Madrasah NWDI memberikan inspirasi untuk ide-ide selanjutnya. 19 3, TGKH. Muhammad Zainudddin Abdul Madjid mendirikan lembaga pendidikan agama khusus perempuan. Ketika saya masih dalam bentuk halaqah di Pondok Pesantren Al- 
Mujahidin, perempuan juga memiliki kesempatan yang sama dengan laki-laki. Sebagai realisasi dari pemikiran tersebut, pada tanggal 15 Rabiul Awal 1362 H/21. Madrasah Nahdlatul Banat Diniyyah Islamiyyah (NBDI) resmi didirikan pada tanggal 1 April 1943. Tidak seperti biasanya, tanggal dan bulan pendiriannya kemudian dikenal sebagai Hari Kartini sebagai tonggak Kebangkitan Perempuan Indonesia. (Abdul Fatah dkk, 2017).

Nahdlatul Wathan fokus pada tiga bidang pembangunan, yaitu pendidikan, sosial dan dakwah. Jumlah lembaga pendidikan yang disponsori NW adalah 1.500 dari tingkat dasar hingga universitas. Perkembangan lembaga pendidikan ini berlangsung melalui peta alun-alun yang tersebar di berbagai wilayah Lombok. NW juga mendirikan panti asuhan untuk anak yatim dan dhuafa. Mereka dikirim ke sekolah dan menerima beasiswa untuk menyelesaikannya. Untuk kegiatan dakwah, guru-guru dari North West melakukan kajian di seluruh desa. Penelitian ini melibatkan jemaah Muslim dan organisasi komunitas Islam Nahdlatul Wathan Muslimah di berbagai desa dan bersifat harian, mingguan, bulanan dan tahunan. NW telah mengembangkan tradisi ritual yang dikenal sebutan hiziban, wiridan, atau zikiran, barzanzi, dan syafa'ah. Nahdlatul Wathan juga mengembangkan seni dengan menciptakan lagu-lagu Arab yang identik dengan khas Nahdlatul Wathan, lagu-lagu Indonesia, dan bahasa Sasak sebagai bahasa daerah Lombok.

Nahdlatul Wathamn Menganut aqidah Ahlussunnah wa Al-Jama'ah menerapkan mazhab Syafi'i sebagai mazhab organisasi tunggal. Asas organisasi NW adalah Pancasila menurut undang-undang no. 8 Tahun 1985. Khittah NW tidak berafiliasi dengan organisasi politik atau sosial manapun. Dalam praktiknya, Khittah ini berbeda karena NW telah aktif terlibat dalam kegiatan politik praktis sejak awal.

Dalam pemilihan parlemen pertama pada tahun 1950, pendiri NW berpartisipasi aktif dalam partai Masyumi dan pada tahun 1952 menjabat sebagai penasihat partai Masyumi untuk organisasi massa lainnya. Ketika orde baru muncul, NW bergabung dengan Sekber Partai Golkar, dan pada tahun 1970 NW resmi bergabung dengan Partai Golkar. (Saipul, 2011). 
Dalam sejarah Nahdlatul Wathan, berdirinya NW dilatarbelakangi oleh "perlunya suatu lembaga yang dapat berperan sebagai koordinator, pembimbing dan pengayom kegiatan Madrasah Nahdlatul Wathan Diniyah Islamiyah (NWDI) dan Madrasah Nahdlatul Banat Diniyah Islamiyah (NBDI), yang telah berkembang pesat dengan banyak cabang, yang memiliki madrasah yang tersebar di berbagai daerah dan kota di pulau Lombok." Kedua lembaga pendidikan yang kemudian bergabung menjadi Pondok Pesantren Darun Nahdlatain NW (PPDNW) Pancor ini adalah ibu kota awal NW, legitimasinya sebagai tempat dan wadah berkompeten bagi ilmu pengetahuan (agama). (Arie, 2015).

Organisasi Nahdlatul Wathan atau yang populer disingkat NW adalah organisasi terbesar di Nusa Tenggara Barat (NTB) yang didirikan oleh seorang ulama kharismatik putra asli Lombok. Setelah al Mujahidah Ummuna Hj Sitti Raihanun Zainuddin Abdul Madjid mengambil alih untuk mendistribusikan kepemimpinan NO pada tanggal 1 . Semua orang saling memandang setelah Ummuna menegaskan bahwa dia tidak akan melangkah lebih jauh. Untuk mencari pengganti pemimpin NW di levelnya, pendapat Muktamirin selaku pengurus Nahdlatul Wathan tentang sosok penerus Maulanasyaikh Zainuddin Atsani, yaitu Tuan Guru Bajang (Jung) KH LG Muhammad Zainuddin Atsani, pemuda visioner dan tokoh agama serta harapan seluruh warga NW untuk membawa organisasi NW NTB di semua dimensi ke dunia internasional. Dengan terpilihnya Tuan Guru Bajang KH Lalu Gede Muhammad Zainuddin Atsani, Lc., M.Pd.I. sebagai Presiden Umum PBNW periode 2019-2024. Administrasi PBNW terdiri dari mantan karakter NW yang, seperti PBNW sebelumnya, penuh dengan pengalaman dan jam terbang. (Hasanah, 2019).

\section{Peranan Tuan Guru pada Sosial-Keagamaan}

Peranan Tuan Guru sangat besar sebagai tokoh agama yang menyebarkan ilmu kepada masyarakat. Sebagaimana didalam karya ilmiah As'ad 2017, Ia mencontohkan bahwa Ulama dan Kyai, serta Tuan Guru, memiliki arti yang hampir sama, hanya istilah yang digunakan saja yang berbeda. Dia memiliki posisi penting dalam Ordo. Secara 
teologis, Tuan Guru adalah pewaris para Nabi, sehingga orang beranggapan bahwa Tuan Guru adalah sumber legitimasi agama dan juga di daerah lain. (As'ad, 2017).

Selain peran dominannya dalam bidang keagamaan, Tuan Guru juga memiliki peran sosial, terutama sejak rezim Orde Baru berkuasa, di mana Tuan Guru digunakan sebagai legitimator segala politik yang berkaitan dengan kehidupan masyarakat. Salah satu peran sosial guru yang penting adalah mewakili masyarakat dalam membangun hubungan dengan pemerintah. Peran ini pada dasarnya bukanlah peran sosial yang harus dimainkan oleh guru, tetapi peran yang didikte oleh pemerintah. Sosok Tuan Guru tidak lepas dari perubahan pandangan masyarakat tentang kedudukan dan peran guru dalam kehidupan mereka. Arus informasi dan tokoh agama baru melalui media turut mempengaruhi perubahan cara pandang ini (As'ad, 2017).

Sebutan Tuan Guru yang harus dihormati dalam masyarakat Sasak di Lombok menurut Firdaus dan Fahrurrozi dalam Artikel Ilmiah Agus, 2014 adalah:

"Penyebutan kata dari Tuan yakni, simbol integritas, keterampilan dan perjuangan. Orang-orang di zaman kuno harus berjuang melintasi lautan, mengamuk badai untuk mendapatkan gelar master "ziarah". Anda harus mempersiapkan diri secara fisik dan mental untuk pergi ke tanah suci Mekkah, memenuhi amanat Allah bagi yang mampu (melakukan haji). Setelah perjalanan itu, ketika dia kembali ke kampung halamannya, dia akan dihormati dan disegani. Kata guru, simbol intelektualitas dan pengabdian masyarakat. Istilah Tuan Guru memadukan dan melambangkan hal di atas, berjuang menegakkan syariat Islam, menyebarkan dakwah dengan akalnya, mengabdi kepada masyarakat. "Bila kita berbicara tentang cita-cita guru masa lalu atau masa awal istilah guru guru, justru penyebutan guru guru yang menyimpang dari bahasa sederhana, ketika orang disebut master atau "guru”, misalnya Guru Muinah, Guru Bangkol, guru itu lebih dari gelar atau guru. Statusnya sangat tinggi, hanya menyebut seorang guru, karena dia memilikinya. Dalam bahasa Weber, keseluruhan adalah karismatik (karismatik, keutuhan). Jadi, dia telah memperoleh totalitas kharismatik karena memiliki etika, akhlak yang baik, walaupun "tidak banyak 
membutuhkan ilmu" tapi tasawufnya didahulukan, akhlaknya di utamakan, dia hanya bisa membaca harmoni, dia sudah bisa menyandang gelar guru, sebagai pribadi yang ditiru dan diajarkan."

Awal mula perkembangan Nahdlatul Wathan sangat menghabiskan banyak waktu dan Saat itu sangat sulit untuk menjadi guru master, tidak seperti hari ini. Sangat mudah bagi orang untuk mendapatkan gelar master yang diakui, terutama dalam mode tertentu seperti politik dan kekuasaan, dari situlah TGH berasal. Munajib dikenal sebagai "Guru kelancungan (Agus, 2014).

Tuan Guru di dalam ruang lingkup Nahdlatul Wathan memberikan lima kriteria umum untuk menyebut seseorang sebagai guru guru; Pertama, keluasan ilmu (agama). Kedua, rahmat-Nya. Ketiga, para ahli telah membaca kitab kuning. TGH. Munajib Khalid dalam karya ilmiah Agus meyakini pendapat Fahurrozi lalu menambahkan; Seseorang disebut Tuan Guru bila memenuhi syarat, mampu menguasai 40 sampai 70 kitab. Harus diakui baik secara ilmiah maupun moral di tengah-tengah masyarakat, semua lapisan masyarakat mengakui bahwa ia layak disebut Tuan Guru. Akhirnya, ia mampu menguasai bahasa yang dimengerti.

Tokoh agama di katakan dengan sebutan Tuan Guru jika dengan baik telah mengikuti berbagai kriteria yang termaksud di dalam golongan tokoh agama. telah memenuhi kriteria tertentu seperti, menguasai ilmu keislaman secara lahir dan batin, belajar ke negara Islam, pernah menyempurnakan rukun agama. Keempat, berperilaku baik di kalangan pendengan kaum muslimin dan secara aktif bersosial dalam masyarakat. (Agus, 2014).

Di berbagai daerah di Indonesia, istilah ulama digunakan berbeda dengan kyai. Fungsi utama ulama adalah peran tradisional dan ortodoks mereka sebagai pelaksana Islam, mengajarkan ajaran agama dan memelihara praktik ortodoks di kalangan umat Islam. 
Makna dari "Tuan Guru" yang berkembang dikalangan suku-suku daerah pulau Lombok identik dengan sebutan "Kyai Haji” yang berkembang di masyarakat Islam khususnya di pulau Jawa. Ia adalah seorang tokoh agama Islam yang diyakini menguasai ajaran Islam dalam berbagai aspek. Tuan Guru (ulama) adalah kata majemuk yang terdiri dari dua suku kata "tuan" dan "guru" Tuan dalam etimologi Sasak (suku di Pulau Lombok Nusa Tengara Barat) yang berarti orang yang telah melakukan ibadah haji ke Makkah, dan guru berarti orang yang mengajar. Dalam terminologi suku sasak yang ada di Lombok, Tuan Guru adalah sekelompok orang yang ahli dalam bidang ilmu keagamaan (Islam) yang mengajar dan membimbing jamaah atau murid-muridnya dalam suatu lembaga formal di madrasah atau pesantren atau lembaga non-formal seperti di masjidmasjid, surau atau pesantren (Masnun, 2008).

Legitimasi keilmuan Islam, Tuan Guru Pancor juga berperan dalam perjuangan kemerdekaan Republik Indonesia (RI) di Lombok. Menggunakan pesantren sebagai tempat penyadaran dan sebagai pusat perjuangan kemerdekaan. Pasca kemerdekaan RI, misalnya, berbagai partai Islam seperti NU dan PSII harus mendapat "berkah" dari Tuan Guru Pancor agar bisa berada di Nusa Tenggara Barat. Aula utama yang menghasilkan ulama sosiokultural adalah lembaga pendidikan, yaitu pondok pesantren. Pengaruh Tuan Guru Pancor di NTB juga karena kemampuannya mengembangkan lembaga pendidikan yang ia ciptakan. Dari tahun 1943 hingga 1997 ia berhasil mendirikan 800 lembaga pendidikan (Arie, 2015).

Pemahaman tentang Islam banyak dipengaruhi oleh banyak kendala yakni kendala yang bersifat internal dan juga yang bersifat eksternal. Perbedaan pemahaman tentang Islam sesungguhnya terjadi tidak hanya saat ini saja, tapi terjadi pada hampir semua zaman karena adanya situasi dan kondisi sosial-politik yang mempengaruhinya. Selain itu latar belakang pendidikan dan guru tempat ia menuntut ilmu pengetahuan merupakan cara yang cukup signifikan dalam membentuk karakter pribadi serta corak pemahaman yang beragam. Arah dan asas perjuangan umat Islam dibangun oleh pemahaman rasional terhadap segala hal yang perlu dan harus di rasionalkan serta jalani arus kebudayaan lokal yang berlaku sampai ajaran Islam lebih cepat di adaptasi dengan 
kebudayaan yang lebih dahulu tumbuh dan berlaku sebagai hukum yang hidup dan mudah di pahami, dan mempermudah pula lika-liku kehidupanya. Organisasi keagamaan yang ada di Lombok seperti Nahdlatul Wathan dan Nahdlatul Ulama yang memahami Islam secara tradisional dan ormas Islam Muhammadiyah yang memahami Islam secara rasional (Nur, 2019).

Pemahaman Islam Masyarakat modern Lombok di Nusa Tenggara Barat lebih banyak dipengaruhi oleh ajaran Islam formal, yang lebih banyak dipengaruhi oleh pendekatan teologis dan fiqh, atau pendekatan hukum dalam arti yang lebih luas atau lebih umum, yaitu.

a. Bidang ibadah. Yakni pada ajaran bidang ini meliputi: 1) tidak selamatan dan kegiatan tahlilan, 2) mendatangi kuburan untuk berziarah dalam hal mengingat akhirat, bahwa semua yang bernyawa akan meninggal dalam hal tidak minta berkah dari kuburan, 3) tidak menggunakan sorban atau kopiah sebagai gelar tokoh agama, 4) mendekatkan diri kepada Tuhan (Allah swt) adalah kunci nasib dan segala permasalahan kehidupan, 5) memotong hewan seperti kambing saat pengakikahan anak setelah lahir, 6) membaca zikir sesudah salat wajib lima waktu sendiri-sendiri tanpa suara keras, 7) melakukan kegiatan makan dan minum bersama dalam pesta dengan cara tidak berdiri.

b. Bidang sosial. Ajaran yang disebut "muamalah" atau "ibadah lainya secara umum" ini seperti: 1) tidak mantaati perintah ulama atau tokoh agama dengan mengecup tangan, 2) tidak harus memakai sajadah bergambar dan tasbih atau memakai peci saat shalat,3) menjaga kehalalan kebersihan pekerjaan, ) rumah bersih dari dekorasi yang melanggar syariat Islam, seperti gambar binatang dan lain-lain, 5) memberi salam ketika bertemu sesama muslim, 6) hidup dan berpakaian sopan, namun akan terasa bahagia menolong antar sesame, 7) perayaan acara perkawinan secara biasa biasa tidak bermegahan, tanpa adanya iringan musik belebihan, 8) menyekolahkan anak ke sekolah berpangkat tinggi atau negeri (Nur, 2019). 


\section{c. Keagamaan dan Sosial (Islam) Lombok, NTB}

Secara umum, istilah identitas sosial mengacu pada definisi diri seseorang dalam hubungannya dengan orang lain. Dalam psikologi sosial, identitas sosial memiliki arti yang lebih spesifik, yaitu definisi diri dalam pengertian menjadi bagian dari kelompok sosial yang berbeda. Identitas sosial adalah konsep sosial umum dari mana ia muncul (Anom, 2008).

Pada karya ilmiah milik Jamaluddin menjelaskan tentang sosial keagamaan yang ada di Lombok, hal itu di lihat dari sejarah penyebaran agama islam dan juga pendiri organisasi masyarakat islam terbesar Nahdlatul Wathan di lombok. Islam di Lombok di perkirakan masuk sekitar 1401 Masehi hingga 1500 Masehi, karena para saudagar muslim saat itu sudah menetap di pulau Lombok. Ketika kerajaan-kerajaan Islam Lombok menunjukkan kemajuannya, peradaban Islam berkembang pesat. Di pusat-pusat kerajaan berkembang tradisi tulis yang melahirkan karya-karya sastra dan penyalinan karya-karya dari luar negeri, seperti Arab, Melayu, dan Jawa, dalam bahasa atau aksara Sasak, yakni suku Lombok. Perubahan politik dari kerajaan islam kepada kerajaan Hindu memiliki pengaruh yang tidak kecil bagi perkembangan islam di Lombok. Kota-kota muslim yang sebelumnya diwarnai oleh mobilitas yang tinggi menjadi stagnan setelah runtuhnya kotakota tersebut (Jamaluddin, 2011).

Pengertian antara stratifikasi sosial dan kelas sosial sering disamakan, sedangkan di sisi lain terdapat perbedaan pengertian antara stratifikasi sosial dan kelas sosial. Stratifikasi sosial mengacu pada pengelompokan orang ke dalam tingkatan atau strata dalam hierarki vertikal. Berbicara tentang stratifikasi sosial berarti mempelajari kedudukan atau kedudukan orang atau sekelompok orang dalam keadaan yang timpang. Oleh karena itu, stratifikasi sering dikaitkan dengan masalah ketimpangan atau polarisasi sosial. Secara historis, keberadaan stratifikasi sosial dalam masyarakat feodal di Lombok Timur tidak lepas dari pengaruh akulturasi budaya, terutama berdasarkan gelar, jabatan, dan lain-lain. Tetapi keberadaan stratifikasi sosial yang sebenarnya di semua masyarakat feodal sudah ada. Namun, dengan adanya pengaruh asing, tidak tertutup kemungkinan yang terjadi bukan hanya bentuk stratifikasi sosialnya saja, tetapi ada juga yang telah 
diberikan jabatan tertentu dan bagaimana gelar tersebut dapat diidentifikasi dalam stratifikasi sosial tersebut. Inilah yang terjadi pada masyarakat Lombok pada umumnya dan Lombok Timur pada khususnya. Pengaruh agama Hindu, Kristen, dan agama lain, baik Jawa maupun Bali, telah memberi warna pada kejelasan stratifikasi sosial pulau ini (Ahmad, 2016).

Ada kata sosial yang disebarkan oleh berbagai agama, budaya Hindu dan agama lain di Nusantara serta pengaruhnya di berbagai daerah seperti Sumatera, Jawa, Bali, dll. Budaya Hindu-Kristen juga menyebar dari daerah ini dan menjadi berbudaya dengan daerah sebelumnya. Misalnya kita mengenal agama Hindu di Bali, untuk menyebutkan beberapa ciri-ciri agama dan budaya Hindu di Bali yang sudah berbudaya budaya aslinya. Namun, satu hal yang dapat dilihat adalah keadaan wilayah peradaban agama, baik di India maupun di wilayah penyebaran agama dan budaya, selalu ada kasta sosial. Seperti di Bali, kita mengenal tingkat strata sosial seperti; brahmana, satria, triwangsa (waisya: india) dan juga jaba (Ahmad, 2016).

Kecakapan sosial Tuan Guru Muhammad Zainuddin Abdul Madjid merupakan wadah kegiatan sosial yang dilakukan guru, hal ini dapat dilihat pada kegiatan sosial yang dilakukan guru, hal ini dapat dilihat pada kegiatan sosial yang dilakukan oleh guru Muhammad Zainuddin Abdul Madjid. sebagai yang paling menonjol adalah peningkatan kualitas sumber daya manusia, melalui lembaga pendidikan yang dimiliki oleh kegiatan keagamaan (pesantren), serta berpartisipasi dalam pelestarian lingkungan, pertahanan dan peningkatan kesehatan dan kesejahteraan umat manusia. masyarakat (Ashadi, 2018).

Keberadaan tuan guru sebagai tokoh agama dalam memberikan ajaran agama di pulau seribu masjid memberikan perasaan berbeda. Memang hal itu menjadi ciri khas tersendiri bagi masyarakatnya. Pengaruhnya terasa di berbagai bidang, tidak hanya di bidang pendidikan, di bidang politik tetapi juga di bidang eksekutif.

Salah satu alasan yang di simpulkan oleh Tuan Guru sebagai tokoh sosial keagamaan yakni menjalankan fungsi sosialnya sebagai penghubung antara masyarakat dengan pemerintah. Peran ini pada dasarnya bukanlah peran sosial yang harus di perankan 
Tuan Guru, namun hal itu sebagai peran yang di kondisikan oleh pemerintah sebagai sebagai pelayan masyarakat. Peran sebagai mediasi ini terkadang membuat Tuan Guru berada dalam posisi rumit yang di mana Tuan Guru di satu sisi adalah tokoh sosialkeagamaan untuk masyarakat yang harus membela kepentingan masyarakat dan bagian dari struktur keagamaan. Namun hal yang seperti ini di sisi lain harus berkewajiban untuk melaksanakan kegiatan pemerintah dalam rangka melaksanaakan program mereka yang hal itu bersifat sangat responsif dan bila tidak berhati-hati hal akan membuat kerusakana pada citra baik wibawa Tuan Guru di kalangan masyarakat (Firdaus; Engkus, 2012).

\section{Simpulan}

Peran seorang figur pemimpin sosial keagamaan sangat penting dalam menunjang keberlangsungan kehidupan beragama. Tradisi keagamaan Islam yang telah ada pada masyarakat Sasak sejak awal lebih menekankan pada penguatan praktik atau ritual keagamaan yang sepintas merupakan ekspresi keagamaan yang sangat penting dalam bentuk skema dasar ritual, yang kemudian menjelma menjadi satu skema dengan penekanan zhahir nash dalam tafsiran pemahaman Islam.

Sosial keagamaan yang baik di masyarakat suku sasak memberikan sumbangasih yang besar untuk kemajuan masyarakat. Sosial keagamaan yang ada di Lombok, hal itu di lihat dari sejarah penyebaran agama islam dan juga pendiri organisasi masyarakat islam terbesar Nahdlatul Wathan di Lombok.

Figur pengarah atau petunjuk dalam sosial keagamaan di Lombok yaitu Tuan Guru yang saat ini sudah menjadi pemangku kepentingan yang memiliki tanggung jawab yang sama dengan pemangku kepentingan lokal. Tuan Guru sebagai pengasuh, pemimpin, komunitas, pengasuh madrasah, pengurus/anggota partai politik dan perumah tangga perguruan tinggi ditempatkan secara strategis untuk memotivasi, meningkatkan partisipasi dan memberdayakan masyarakat. Idealnya, umat beragama nasional Indonesia tidak bisa menandingi kondisi daerah dan suku lain. Partisipasi pemuka agama sebagai pemuka agama sangat diperlukan sebagai panutan bagi masyarakat. 


\section{DAFTAR PUSTAKA}

A.A. Ngr Anom Kumbara, 2008, :Konstruksi Identitas Orang Sasak di Lombok Timur, Nusa Tenggara Barat", Jurnal Humanmiora, Vol. 20 No. 3 Oktober. https://journal.ugm.ac.id/jurnal-humaniora/article/view/947.

Abdul Fatah dk, 2017, "Dari Nahdlatul Wathan untuk Indonesia Perjuangan TGKH Muhammad Zainuddin Abdul Madjid (1980-1977)”, Dinas Sosial NTB.

Abdul Shomad, 2015. "Hukum Islam Penormaan Prinsip Syariah dalam Hukum Indonesia", Jakarta: PT. Raja Grafindo Persada.

Agus Dedi Putrawan, 2014, "Dekarismatisasi Tuan Guru di Pulau Lombok Nusa Tenggara Barat:, Jurnal In Right, Vol. 5 No. 2. http://ejournal.uinsuka.ac.id/syariah/inright/article/view/1265.

Ahmad Afandi, 2016, "Stratifikasi Sosial (Sistem Sosial Kulktur) Masyarakat Sasak di Kabupaten Lombok Timur Nusa Tenggara Barat", Jurnal Crikestra, Vol. 5 No. 9 Februari. https://ejournal.unsri.ac.id/index.php/criksetra/article/view/4796.

Arie Oktara, 2015, "Politik Tuan Guru di Nusa Tenggara Barat" Jurnal Ilmu $\begin{array}{llllll}\text { Pemerintahan, } & \text { Vol. } & 8 & \text { No. } & 2 & \text { Juli. }\end{array}$ http://journal.unhas.ac.id/index.php/government/article/view/105/pdf.

As'ad Isma, 2017, "Peran Sosial Tuan Guru dalam Masyarakat Seberang Kota Jambi: Satu Tinjauan Ulang", Jurnal Kontekstualita, Vol. 34 No. 2. http://ejournal.lp2m.uinjambi.ac.id/ojp/index.php/Kontekstualita/article/download/43/22

Ashadi, 2018, "Nahdlatul Wathan dalam Gerakan Islam di Nusantara" Tesis, Pascasarjana UIN Maulana Malik Ibrahim Malang, Prodi Studi Ilmu Agama Islam.

Firdaus Yuni Dharta. Engkus Kuswarno, 2012, "Komunikasi Tuan Guru Sebagai Motiovator di Pesantren" Jurnal Sosiohumaniora, Vol. 14 No. 1 Maret. http://jurnal.unpad.ac.id/sosiohumaniora/article/view/5479.

Fitriyani, 2010, “Organisasi Islam dan Pengembangan Hukum Islam di Indonesia” Jurnal AL-Ulum, Vol $\quad 10, \quad$ No. https://journal.iaingorontalo.ac.id/index.php/au/article/view/12.

Hasanah Efendi, 2019, “Meneropong Arah Baru PBNW 'Milenial' 2019-2024”, Diakses pada tanggal 1 Agustus 2021 20:25 wita di https://suararinjaninews.co.id?p=6175.

Jamaluddin, 2011, Islam Sasak: Sejarah Sosial Keagamaan di Lombok (Abad XVI-XIX), Jurnal Indo-Islamika, Vol. 1 No. 1. http://journal.uinjkt.ac.id/index.php/indoislamika/article/view/1487. 
Lombok Group News. 2017. Sekilas Tentang NW, Organisasi Masyarakat Terbesar Di Pulau Lombok-NTB. https://news.lombokgroup.com/2017/11/sekilas-tentang-nworganisasi-masyarakat-terbesar-di-pulau-lombok-ntb/

Masnun Tahir, 2008, “Tuan Guru dan Dinamika Hukum Islam di Pulau Lombok”, Jurnal $\begin{array}{lllll}\text { Asy-Syirah } & \text { Vol. } & 42 & \text { No. } & 1 .\end{array}$ suka.com/index.php/AS/article/view/251.

Mohammad Iwan Fitriani, 2016, "Kepemimpinan Kharismatis-Transformatif Tuan Guru dalam Perubahan Sosial Masyarakat Sasak-Lombok Melalui Pendidikan”, Jurnal $\begin{array}{llllll}\text { Al-Tahrir, } & \text { Vol. } & 16 & \text { No. } & 1 & \text { Mei. }\end{array}$ https://jurnal.iainponorogo.ac.id/index.php/tahrir/article/view/332.

Nur Latifah, 2019, "Pola Keberagaman Masyarakat Islam di Lombok Nusa Tenggara Barat", Jurnal; $\quad$ Elkatarie Vol. $22 \quad$ No. 1. http://ejournal.kopertais4.or.id/sasambo/index.php/elkatarie/article/view/3649.

Saipul Hamdi, 2011, "Politik Islam: Re-Negosiasi, Konflik, dan Kekuasaan dalam Nahdlatul WEathan di Lombok Timur, Jurnal Kawistara Vol. 1 No. 1, 21 April. https://jurnal.ugm.ac.id/kawistara/article/view/3902/3187. 